\title{
RANCANG BANGUN MESIN PEMINTAL AGEL
}

\section{Design of Agel Spinner Machine}

\author{
Aan Eddy Antana, Demas YogoPranoto, dan Sulistyono \\ Balai Besar Kerajinan dan Batik, Jl. Kusumanegara No.7 Yogyakarta \\ aan.eddy@gmail.com
}

Tanggal Masuk: 22 September 2016

Tanggal Revisi: 07 November 2016

Tanggal disetujui: 16 November 2016

\begin{abstract}
ABSTRAK
Industri kerajinan agel telah ada dan berkembang di beberapa wilayah di Indonesia. Sentra industri tali (tampar) agel berada di Desa Kapasan, Kecamatan Nguling, Kabupaten Pasuruan, sedangkan sentra industri kerajinan agel berada di Kecamatan Sentolo, Kabupaten Kulonprogo. Industri ini menghasilkan berbagai macam produk kerajinan bernilai ekonomi tinggi seperti; tas, topi, furnitur, noken dan masih banyak lagi produk kerajinan lainnya. Permasalahan yang dihadapi industri kerajinan agel adalah proses produksi dilakukan secara manual dengan keterbatasan pada kapasitas produksi dan ketidakstabilan kualitas produk bahan baku tali agel. Tujuan penelitian ini adalah untuk membuat prototipe mesin pintal agel yang dapat mempersingkat tahapan proses dan meningkatkan kapasitas produksi industri kerajinan agel. Metode yang digunakan yaitu pengumpulan data melalui survei literatur dan lapangan, perancangan desain, penyiapan bahan dan alat, pembuatan mesin, uji coba dengan variabel kecepatan putaran dan panjang agel, analisa dan pembahasan hasil uji coba. Penelitian ini menghasilkan satu unit mesin pemintal agel dengan spesifikasi panjang: $110 \mathrm{~cm}$, lebar: $46 \mathrm{~cm}$, tinggi: $90 \mathrm{~cm}$, penggerak motor listrik 1 phase, 220 volt, 250 watt, $1400 \mathrm{rpm}$. Mesin ini mempunyai kapasitas maksimal pada putaran $700 \mathrm{rpm}$, panjang agel $100 \mathrm{~cm}$, yaitu $4700 \mathrm{~cm} / \mathrm{jam}$. Mesin ini mampu meningkatkan kapasitas sebesar 56,67\% dibandingkan pemintalan manual.
\end{abstract}

Kata Kunci: Rancang bangun, mesin, pemintal, agel

\begin{abstract}
Agel craft industry has existed and developed in several regions in Indonesia. The center of agel's rope industry is in Kapasan, Nguling, Pasuruan, while the center of agel craft industry is in Sentolo Kulonprogo. This industry produces a wide range of handicraft products of high economic value such as bags, hats, furniture, noken and many other craft products. Problems of conventional agel crafts industry are the limited availability and uniformity agel's rope. The purpose of this research is to create a prototype of an agel spinner machine that can reduce the stage of the process and increase the capacity of the agel craft industry. The method used are the collection of data through literature and field survey, design planning, preparation of materials and tools, making tools, testing with variable rotation speed and length of agel, analysis and discussion of test results. The result of this research is one unit of agel spinner machine with specifications length: $110 \mathrm{~cm}$, width: $46 \mathrm{~cm}$, height: $90 \mathrm{~cm}$, with an electric motor 1 phase, 220 volt, 250 watt, $1400 \mathrm{rpm}$. This machine has a maximum capacity at $700 \mathrm{rpm}$, agel length of $100 \mathrm{~cm}$, is $4700 \mathrm{~cm} / \mathrm{h}$. This machine is able to increase capacity by $56,67 \%$ compared to manual spinning.
\end{abstract}

Keywords: design, machine, spinner, agel 


\section{PENDAHULUAN}

Gebang (Corypha gebanga BL), seperti terlihat pada Gambar 1 adalah nama sejenis palma, biasa hidup di daerah dataran rendah hingga ketinggian sekitar $300 \mathrm{~m}$ di atas permukaan laut. Ketinggian pohon ini mencapai 15-20 m, daunnya berbentuk kipas dan berduri. Tumbuhan ini banyak tersebar di wilayah Indonesia, sehingga sangat potensial untuk dikembangkan menjadi industri kreatif. Daun gebang terutama yang muda diolah menjadi berbagai bahan anyaman yang bagus; untuk bahan membuat tikar, topi, kantong, karung, tali, jala dan pakaian tradisional.

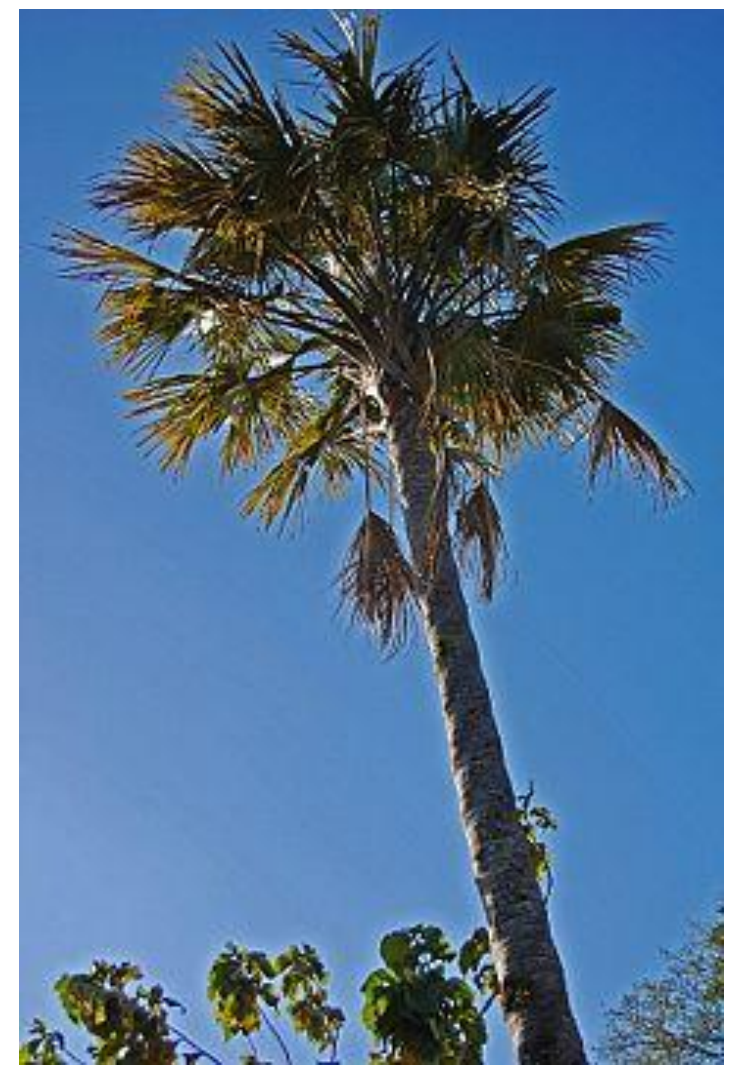

Gambar 1. Pohon Gebang

(Corypha gebanga BL)

Agel dihasilkan dari pembelahan daun yang masih muda (pucuk) dari tanaman gebang. Pengolahan pucuk daun dengan cara membelah menggunakan pisau dapur secara manual, menghasilkan agel di bagian atas, gajih di bagian bawah, dan gabul sebagai hasil serutan gajih. Agel diwarnai dan dikeringkan untuk selanjutnya dipintal menjadi tali atau ditenun menjadi produk bagor. Memintal merupakan proses penggabungan dua tali setengah jadi dari proses pilin menjadi satu bagian yang disebut dengan tampar (Wardhana, 2013). Proses pemintalan agel secara manual menggunakan paha atau ban dalam bekas sebagai alas. Proses pemintalan manual seperti terlihat pada Gambar 2.

Tali agel selanjutnya dibentuk dengan teknik rajut ataupun ditenun membentuk jaring (Widiastuti, 2011).

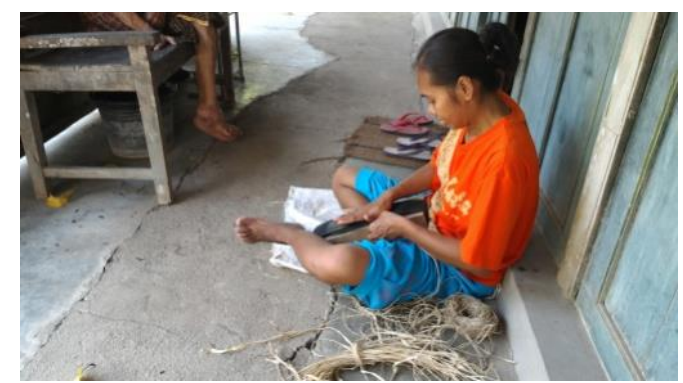

Gambar 2. Pemintalan manual

Kelompok industri kerajinan yang bahan bakunya menggunakan tampar agel telah ada dan berkembang di beberapa wilayah di Indonesia. Sentra industri tampar agel berada di Desa Kapasan, Kecamatan Nguling, Kabupaten Pasuruan. Tampar agel seperti terlihat pada Gambar 3 dijadikan bahan baku untuk berbagai produk kerajinan.

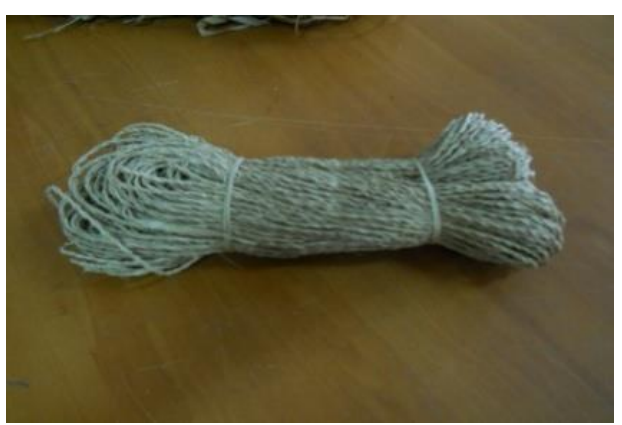

Gambar 3. Tampar agel 
Sentra industri kerajinan agel berada di Kecamatan Sentolo, Kabupaten Kulonprogo. Industri ini menghasilkan aneka kerajinan yang bernilai tinggi seperti tas, topi, alas meja hingga tempat lampu yang siap dipasarkan (Soraya, 2011). Selain itu, tali agel juga dapat dimanfaatkan sebagai bahan baku noken, tas tradisional masyarakat Papua yang ditetapkan sebagai warisan budaya tak benda UNESCO pada tanggal 4 Desember 2012. Contoh produk kerajinan agel seperti terlihat pada Gambar 4.

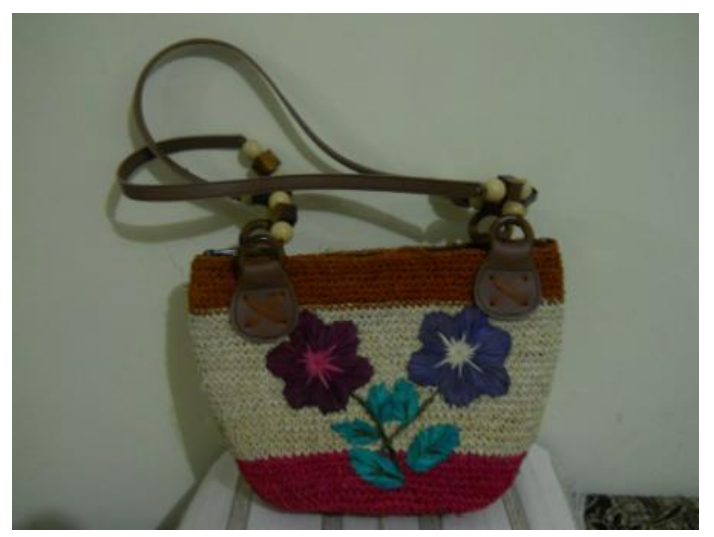

Gambar 4. Tas agel

Kerajinan agel sampai sekarang masih terkendala dalam hal ketersediaan dan keseragaman bahan baku tali. Hal ini disebabkan dalam pembuatan tali agel masih dilakukan secara manual. Para pengrajin lebih memilih membeli bahan baku yaitu tampar serat agel dari luar daerah, hal ini dikarenakan pilinan tampar serat agel yang mereka lakukan sebelumnya hanya secara manual sehingga kualitas pilinannya kurang bagus dan memerlukan waktu yang sangat lama, sedangkan dengan membeli kualitasnya jauh lebih bagus (Paryanto, 2011). Rekayasa mesin pintal agel yang telah dilakukan belum mampu menghasilkan pintalan sebaik pintalan manual.
Proses pemintalan merupakan proses pembuatan benang dengan memilin dan menjalin secara bersama serat-serat tumbuhan atau hewan. Memintal merupakan salah satu dari beberapa seni terkuno. Apa pun metode pemintalan yang digunakan, pilinan benang yang terjadi akan berbentuk huruf $\mathrm{S}$ atau $\mathrm{Z}$, artinya garis-garis seratnya merupakan alur yang condong ke kiri atau ke kanan, bila benang ditegakkan.

Ramanda (2013) mengadakan penelitian perancangan ulang mesin pilin tampar pandan dan rancangannya diharapkan mampu mengurangi keluhan fisik pengrajin serta meningkatkan produktivitas.

Yusuf (2011) dalam penelitiannya tentang perancangan mesin pintal tampar pandan yang ergonomis mengatakan bahwa pembuatan tampar pandan terdiri dari dua proses yaitu proses pilin dan proses pintal dan harus dilakukan secara berurutan. Kedua proses ini masih dikerjakan dengan menggunakan mesin tradisional yang sama. Posisi kerja untuk proses leles (pilin) adalah duduk, sedangkan posisi kerja untuk proses pintal adalah berdiri. Produktivitas pengrajin tampar pandan masih tergolong cukup rendah dengan menggunakan mesin yang lama. Penyebab utamanya karena mesin lama yang digunakan menyebabkan keluhan musculoskeletal.

Penelitian ini bertujuan untuk membuat prototipe mesin pintal agel yang dapat mempersingkat tahapan proses dan meningkatkan kapasitas produksi industri kerajinan agel. 
METODOLOGI

\section{Rancangan Penelitian}

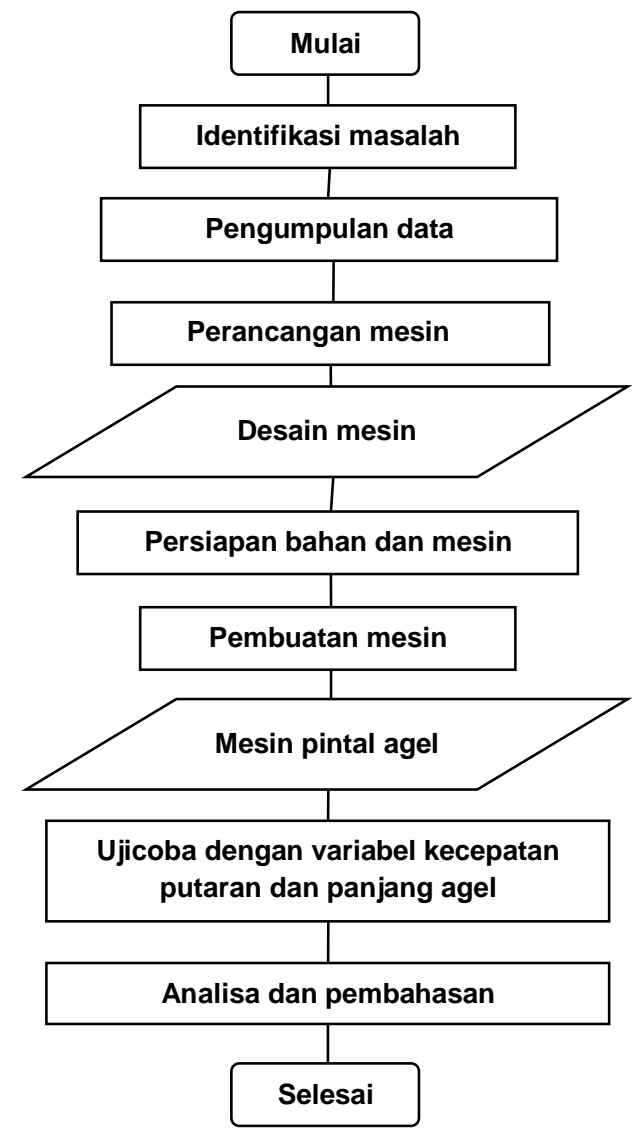

Gambar 5. Flowchart penelitian

\section{Bahan}

Bahan yang digunakan dalam penelitian ini dibagi menjadi dua bagian yaitu bahan pembuat mesin meliputi motor listrik, besi siku, besi plat, besi as, puli, roda gigi, vbelt, bantalan, kawat strimin, mur baut, pegas, kelos dan cat serta bahan uji coba berupa serat agel.

\section{Alat}

Alat yang digunakan dalam penelitian ini yaitu mesin gergaji, mesin bubut, mesin bor, mesin gerinda, las listrik dan seperangkat mesin cat.

\section{Metode}

Identifikasi masalah dilakukan untuk mengetahui permasalahan yang ada pada proses pemintalan baik pemintalan manual maupun pemintalan menggunakan mesin.

Pengumpulan data melalui studi literatur dan lapangan. Studi literatur dilakukan dengan mempelajari jurnal-jurnal terdahulu terkait mesin pintal, teknologi pemintalan dan elemen mesin. Studi lapangan dilakukan melalui wawancara dengan pengrajin.

Perancangan mesin menggunakan software solidwork. Perancangan mesin mempertimbangkan beberapa hal yaitu energi yang dibutuhkan seminimal mungkin, bahan baku mudah didapat, pengoperasian dan pemeliharaan mudah dan sederhana serta harga terjangkau oleh industri kecil. Desain mesin seperti terlihat pada Gambar 6-9.

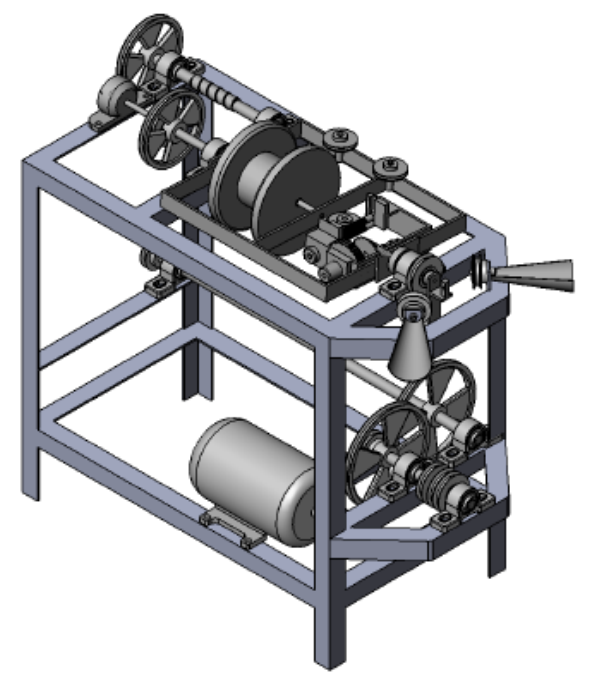

Gambar 6. Perspektif

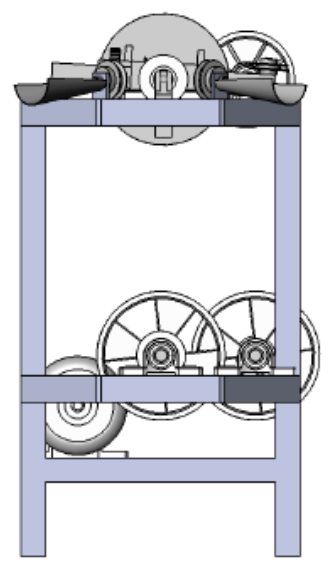

Gambar 7. Tampak depan 


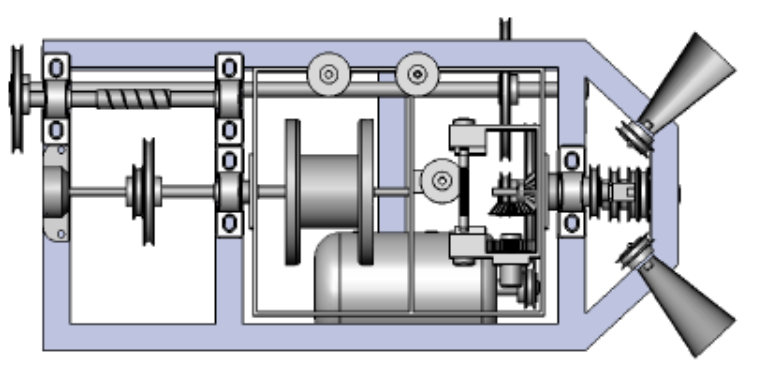

Gambar 8. Tampak atas

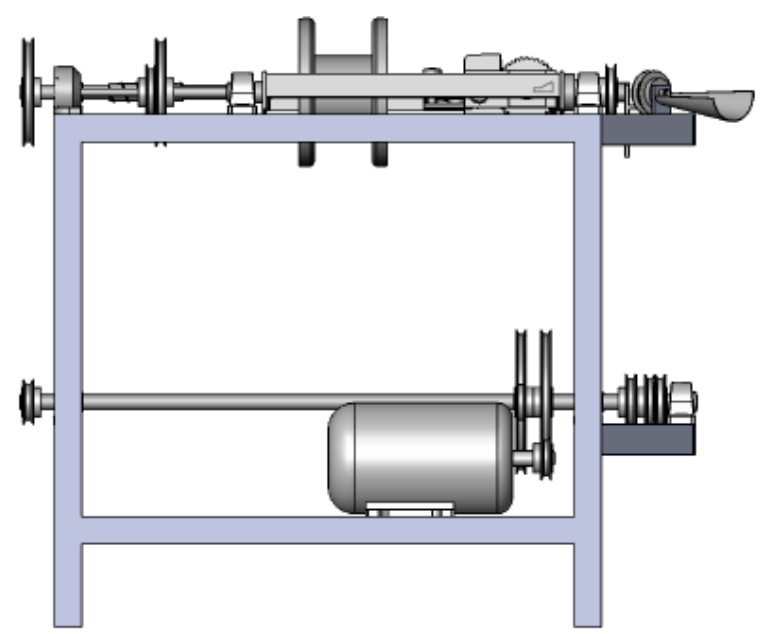

Gambar 9. Tampak samping

Persiapan bahan meliputi bahan yang dibutuhkan untuk mewujudkan mesin pintal sesuai dengan desain mesin. Persiapan mesin meliputi permesinan yang dibutuhkan untuk proses produksi pembuatan mesin pintal.

Pembuatan mesin meliputi pembuatan komponen dan perakitan/assembling, melalui beberapa proses yaitu pengukuran, pemotongan, pembubutan, pengeboran, pengelasan, penggerindaan dan pengecatan.

Uji coba dilakukan di laboratorium keteknikan BBKB dengan variabel kecepatan putaran poros utama dan panjang agel, dengan rol penarik berdiameter $2 \mathrm{~cm}$ pada tiga perbandingan kecepatan putaran yaitu 9:5:1, 18:5:1 dan 27:5:1.

Analisa dan pembahasan dilakukan untuk mendapatkan kecepatan putaran poros utama paling optimal dan perbandingan yang tepat antara kecepatan putaran pemilinan, pemintalan dan rol penarik.

\section{HASIL DAN PEMBAHASAN \\ Hasil Penelitian}

Dari penelitian yang dilakukan, diperoleh protoype mesin pintal agel seperti terlihat dalam Gambar 10 dengan spesifikasi sebagai berikut:

$\begin{array}{ll}\text { Penggerak } & : \text { motor listrik 1 phase, } 220 \\ & \text { volt, } 250 \text { watt, } 1400 \mathrm{rpm} \\ \text { Panjang } & : 110 \mathrm{~cm} \\ \text { Lebar } & : 46 \mathrm{~cm} \\ \text { Tinggi } & : 90 \mathrm{~cm}\end{array}$

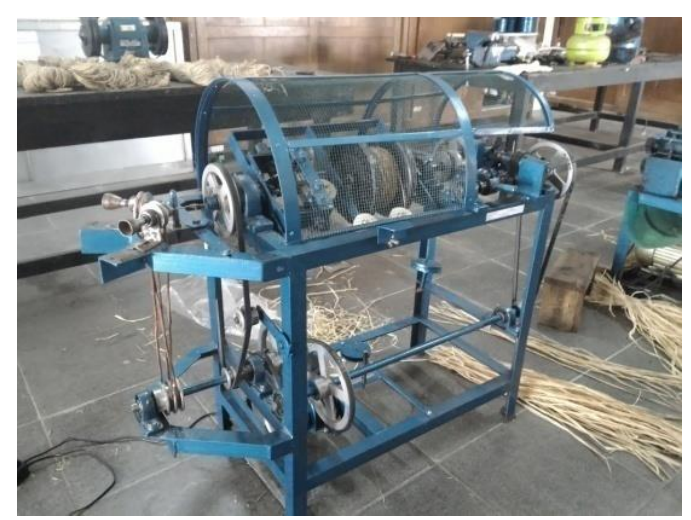

Gambar 10. Prototype mesin pintal agel

Pada Gambar 10 terlihat bahwa prototype mesin tidak sama persis dengan gambar desain. Untuk meningkatkan unjuk kerja, dilakukan perubahan pada bagian pemilin. Selain itu, untuk keamanan dan keselamatan kerja, ditambahkan tutup pengaman. Perubahan dan penambahan ini tidak mengubah prinsip kerja mesin.

Pemilihan bentuk mengadopsi alat pintal pandan manual yang sudah ada dengan beberapa modifikasi.

Mesin pemintal agel ini tidak membutuhkan komponen dengan spesifikasi khusus, karena tidak menahan beban besar dan tidak memakai bahan yang berbahaya sehingga komponen yang tersedia di pasaran pun sudah memadai. 
Proses pemilinan menggunakan mekanisme puntir dan tarik. Sedangkan proses pemintalan menggunakan mekanisme putar dan tarik.

\section{Cara Kerja Mesin}

Mesin pintal agel terdiri dari empat bagian utama, yaitu penggerak, bagian pemilin, bagian pemintal dan bagian penggulung. Putaran dari motor listrik ditransmisikan ke poros utama menggunakan sistem transmisi puli seperti terlihat pada Gambar 11.

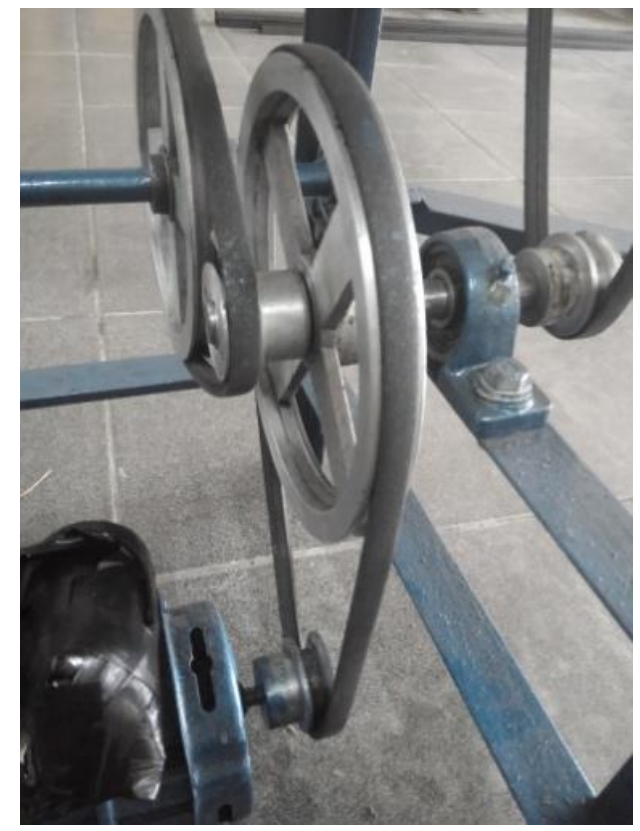

Gambar 11. Transmisi dari motor listrik ke poros utama

Putaran poros utama ditransmisikan ke bagian pemilin, bagian pemintal dan bagian penggulung dengan rasio kecepatan masingmasing 2:3, 3:1 dan 4:1 menggunakan sistem transmisi puli seperti terlihat pada Gambar 12. Sistem transmisi puli dipilih karena sederhana, mampu beroperasi pada putaran tinggi dan tidak menimbulkan kebisingan.

Bagian pemilin seperti terlihat pada Gambar 13 terdiri dari dua lubang input yang berputar dengan kecepatan dan arah putaran sama. Bagian pemilin ini berfungsi untuk memutar agel menjadi pilinan dan sebagai pintu masuk agel ke proses pemintalan.

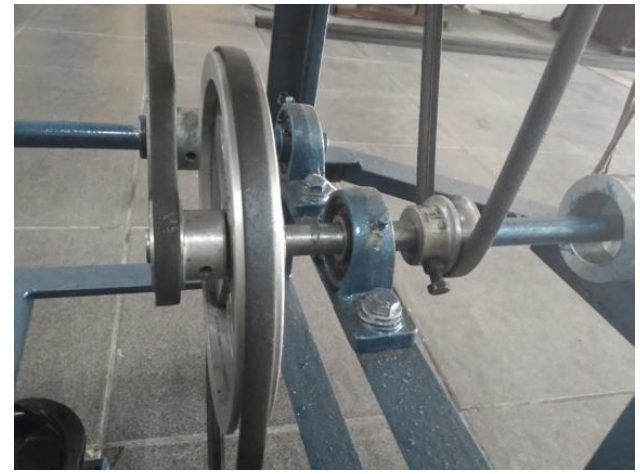

Gambar 12. Transmisi dari poros utama ke poros pemilin, pemintal dan penggulung

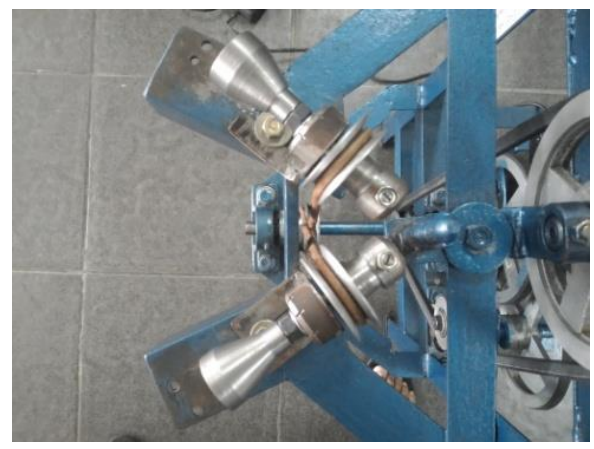

Gambar 13. Bagian pemilin

Di dalam lubang input, masing-masing dilengkapi dengan penjepit yang terdiri dari bola besi dengan diameter $5 \mathrm{~mm}$ dan pegas tekan. Penjepit ini berfungsi untuk menjepit agel agar berputar mengikuti putaran poros pemilin. Pegas tekan berfungsi untuk mengatur kekuatan penjepitan sehingga agel dapat berputar mengikuti putaran poros pemilin dan dapat bergerak mengikuti tarikan rol penggulung.

Kekuatan penjepitan dapat diatur sesuai dengan besar kecilnya agel yang dipintal. Penjepitan yang terlalu lemah mengakibatkan terjadinya selip, sehingga kecepatan putaran agel tidak sesuai dengan kecepatan putaran poros. Penjepitan yang 
terlalu kuat mengakibatkan sulitnya proses penyambungan dan putusnya agel sebelum masuk ke proses pemintalan.

Bagian pemintal seperti terlihat pada Gambar 14 terdiri dari poros pemintal dan rol penarik. Poros pemintal berfungsi memintal agel setelah melewati proses pemilinan. Hasil pemintalan kemudian ditarik oleh rol penarik menuju bagian penggulung.

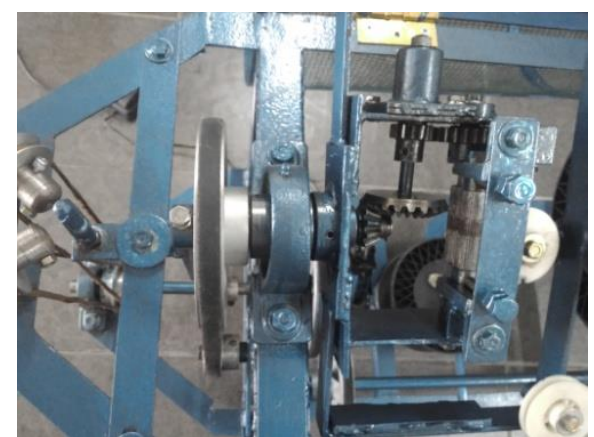

Gambar 14. Bagian pemintal

Perbandingan kecepatan putaran poros pemilin, poros pemintal dan rol penarik sebesar 18:5:1. Ujicoba dilakukan dengan rol penarik berdiameter $2 \mathrm{~cm}$ pada tiga perbandingan kecepatan putaran yaitu 9:5:1, 18:5:1 dan 27:5:1. Tampar agel hasil ujicoba masing-masing perbandingan seperti terlihat pada Gambar 15-17.

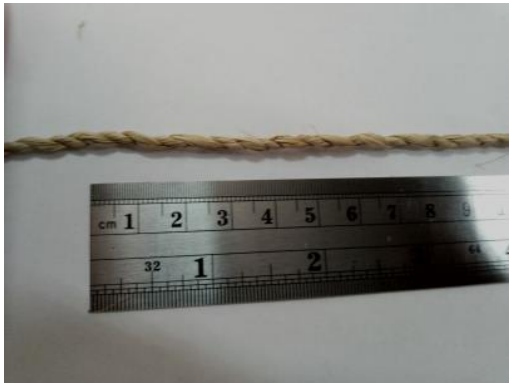

Gambar 15. Tampar agel, perbandingan 9:5:1

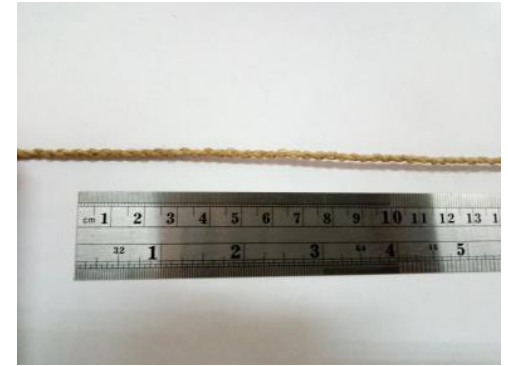

Gambar 16. Tampar agel, perbandingan 18:5:1

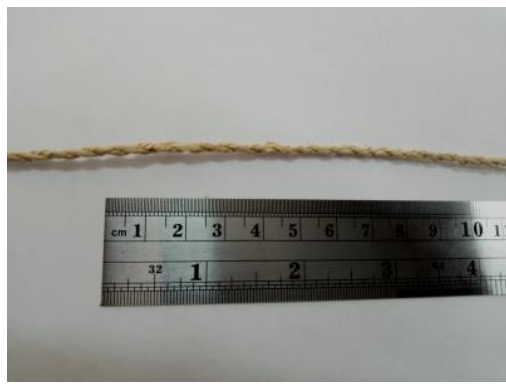

Gambar 17. Tampar agel, perbandingan 27:5:1

Pada Gambar 15 terlihat tampar yang dihasilkan kurang baik, pintalan rapat tetapi pilinan tidak padat. Pada Gambar 16 terlihat tampar yang dihasilkan baik, pintalan cukup rapat dan pilinan padat. Pada Gambar 17 terlihat tampar yang dihasilkan kurang baik, pintalan kurang rapat meskipun pilinan padat. Selain itu, pada perbandingan 27:5:1, sering terjadi putus pada saat proses pemilinan. Hal ini disebabkan oleh puntiran yang berlebihan pada agel.

Bagian penggulung seperti pada Gambar 18 terdiri dari sistem transmisi dan kelos. Sistem transmisi menggunakan puli dan roda gigi yang berfungsi mengubah gerak rotasi menjadi gerak translasi untuk menggerakkan kelos maju mundur sehingga tampar agel tergulung merata di dalam kelos. Kecepatan putaran kelos bersifat fleksibel dengan sistem selip dan pemberat, sehingga kekencangan penggulungan relatif stabil. Kelos dapat dipasang dan dilepas untuk memudahkan pengambilan tampar agel yang dihasilkan. 


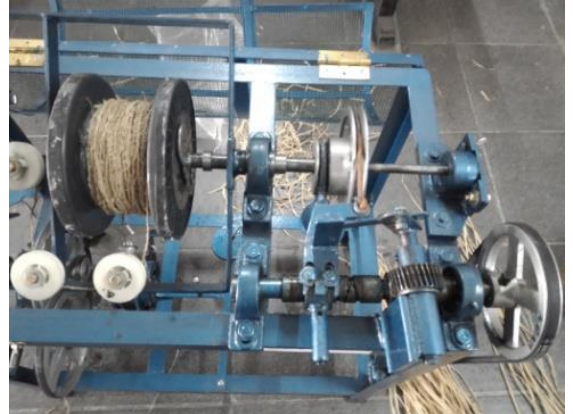

Gambar 18. Bagian penggulung

\section{Uji coba}

Uji coba dilakukan di Laboratorium Keteknikan Balai Besar Kerajinan dan Batik dengan variabel kecepatan putaran poros utama dan panjang agel. Ujicoba dilakukan menggunakan perbandingan kecepatan putaran terbaik (18:5:1) oleh seorang operator tanpa keahlian khusus dengan beberapa variasi kecepatan putaran dan panjang agel. Panjang agel yang digunakan yaitu $50 \mathrm{~cm}, 75 \mathrm{~cm}$, dan $100 \mathrm{~cm}$. Hal ini disesuaikan dengan ketersediaan agel IKM. Hasil ujicoba seperti terlihat pada Tabel 1-4.

Tabel 1. Kapasitas pada putaran $350 \mathrm{rpm}$

\begin{tabular}{ccc} 
No & $\begin{array}{c}\text { Panjang agel } \\
(\mathrm{cm})\end{array}$ & $\begin{array}{c}\text { Kapasitas } \\
(\mathrm{cm} / \mathrm{jam})\end{array}$ \\
\hline 1 & 100 & 2000 \\
\hline 2 & 75 & 1400 \\
\hline 3 & 50 & 1200 \\
\hline
\end{tabular}

Tabel 2. Kapasitas pada putaran $500 \mathrm{rpm}$

\begin{tabular}{ccc} 
No & $\begin{array}{c}\text { Panjang agel } \\
(\mathrm{cm})\end{array}$ & $\begin{array}{c}\text { Kapasitas } \\
(\mathrm{cm} / \mathrm{jam})\end{array}$ \\
\hline 1 & 100 & 3000 \\
\hline 2 & 75 & 2400 \\
\hline 3 & 50 & 1700 \\
\hline
\end{tabular}

Tabel 3. Kapasitas pada putaran $700 \mathrm{rpm}$

\begin{tabular}{ccc} 
No & $\begin{array}{c}\text { Panjang agel } \\
(\mathrm{cm})\end{array}$ & $\begin{array}{c}\text { Kapasitas } \\
(\mathrm{cm} / \mathrm{jam})\end{array}$ \\
\hline 1 & 100 & 4700 \\
\hline 2 & 75 & 3500 \\
\hline 3 & 50 & 2400 \\
\hline
\end{tabular}

Tabel 4. Kapasitas pada putaran $900 \mathrm{rpm}$

\begin{tabular}{ccc} 
No & $\begin{array}{c}\text { Panjang agel } \\
(\mathrm{cm})\end{array}$ & $\begin{array}{c}\text { Kapasitas } \\
(\mathrm{cm} / \mathrm{jam})\end{array}$ \\
\hline 1 & 100 & 3500 \\
\hline 2 & 75 & 2600 \\
\hline 3 & 50 & 1800 \\
\hline
\end{tabular}

Perbandingan kapasitas untuk masingmasing kecepatan putaran dan panjang agel seperti terlihat pada Gambar 19.

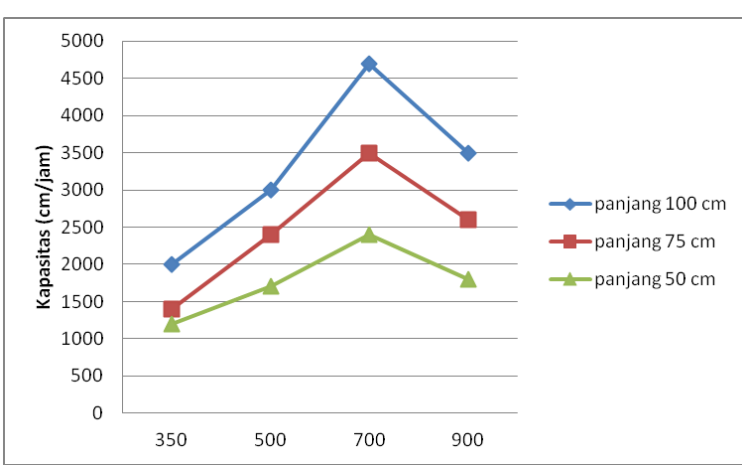

Gambar 19. Grafik kapasitas pada variasi putaran dan panjang agel

Dari uji coba yang dilakukan, kapasitas paling besar didapatkan pada putaran 700 rpm. Kapasitas mesin mengalami kenaikan pada kecepatan putaran 350 rpm sampai 700 rpm dan mengalami penurunan pada 700 rpm sampai $900 \mathrm{rpm}$.

Semakin cepat putaran poros utama, semakin cepat proses pemilinan dan pemintalan yang terjadi. Namun, setelah mencapai kapasitas maksimal, yaitu pada putaran $700 \mathrm{rpm}$, penambahan kecepatan putaran justru menurunkan kapasitasnya. Hal ini disebabkan pada kecepatan putaran kurang dari $700 \mathrm{rpm}$, operator masih mampu menyiapkan dan memasukkan bahan baku sesuai dengan kecepatan putaran poros utama. Sedangkan pada kecepatan putaran lebih dari $700 \mathrm{rpm}$, operator tidak mampu menyiapkan dan memasukkan bahan baku sesuai dengan kecepatan putaran poros utama. Selain itu, pada kecepatan putaran di 
atas $700 \mathrm{rpm}$ sering terjadi putus saat proses pemilinan sehingga harus dilakukan penyambungan yang membutuhkan waktu relatif lama.

Semakin panjang agel, semakin tinggi kapasitas mesin. Hal ini disebabkan semakin panjang agel yang digunakan, semakin jarang proses penyambungan yang dilakukan.

Dari survey lapangan, kapasitas ratarata pemintalan manual sebesar 3000 $\mathrm{cm} / \mathrm{jam}$. Kapasitas maksimal mesin pintal agel ini sebesar $4700 \mathrm{~cm} / \mathrm{jam}$, meningkat sebesar 56,67\% dibandingkan kapasitas pemintalan manual. Penggunaan mesin pintal ini memang tidak memberikan kenaikan kapasitas yang signifikan, namun mempunyai beberapa kelebihan dibandingkan proses manual yaitu lebih ergonomis, pengoperasian mudah, sederhana dan tidak membutuhkan operator khusus.

Mesin pintal agel hasil penelitian ini mempunyai keunggulan jika dibandingkan dengan mesin pintal serat alam lainnya yang mempunyai sifat-sifat hampir sama dengan agel. Mesin pintal ini melakukan dua proses, yaitu pemilinan dan pemintalan. Mesin pintal serat alam yang ada proses pemilinannya terpisah dan dilakukan sebelum proses pemintalan.

\section{KESIMPULAN DAN SARAN Kesimpulan}

Penelitian ini menghasilkan mesin pintal agel dengan spesifikasi panjang 110 $\mathrm{cm}$, lebar $46 \mathrm{~cm}$, tinggi $90 \mathrm{~cm}$ dengan penggerak motor listrik 1 phase, $220 \mathrm{~V}, 250$ watt, $1400 \mathrm{rpm}$.

Mesin pemintal agel ini mempunyai kapasitas maksimal sebesar $4700 \mathrm{~cm} / \mathrm{jam}$, meningkat sebesar $56,67 \%$ dibandingkan pemintalan manual.
Mesin pintal ini mampu memperpendek tahapan proses pembuatan tali agel, yaitu dengan menghilangkan proses prapengelosan. Hal ini dikarenakan serat agel dapat langsung diumpan untuk proses pilin dan pintal.

Mesin pintal ini menghasilkan tali agel paling baik dengan kapasitas maksimal pada perbandingan kecepatan putaran poros pemilin, poros pemintal dan rol penarik sebesar 18:5:1, putaran poros utama 700 rpm dan panjang agel $100 \mathrm{~cm}$.

\section{Saran}

Perlu dilakukan penghitungan tekno ekonomi untuk mengetahui layak atau tidaknya mesin ini diterapkan di industri. Selain itu sebaiknya dilakukan penelitian lebih lanjut untuk meningkatkan unjuk kerja mesin pintal agel ini.

\section{UCAPAN TERIMA KASIH}

Penulis menyampaikan terima kasih kepada Balai Besar Kerajinan dan Batik sebagai penyandang dana penelitian ini melalui dana DIPA tahun 2015, tim keteknikan Balai Besar Kerajinan dan Batik, serta semua pihak yang telah turut serta baik secara langsung ataupun tidak langsung dalam pelaksanaan penelitian ini.

\section{DAFTAR PUSTAKA}

Paryanto, Siti, M., \& Rahmawaty Penny. (2011). Peningkatan Produktivitas Kelompok Pengrajin Berbahan Baku Serat Alami di Sentolo Kab upaten Kulon Progo Melalui Konsep Proses Produksi Terpadu. Program IPTEK Bagi Masyarakat, 1-17. Retrieved from staff.uny.ac.id/sites/default/files /pengabdian/penny...msi/artikel-ibmserat-agel.pdf

Ramanda, A. G. (2013). Perancangan Ulang Alat Pilin Pandan di Desa Tanjungharjo, Nanggulan. Retrieved 
from http://e-journal.uajy.ac.id/id/ eprint $/ 4026$

Soraya, P. (2011). Studi Industri Kerajinan Serat Agel di Desa Salamrejo Kecamatan Sentolo Kabupaten Kulonprogo. UNY. Retrieved from http://eprints.uny.ac.id/538/1/putrisoray a_06405244014.pdf

Wardhana, D. S. (2013). Analisis Postur Kerja dan Biomekanika pada Aktivitas Memintal Daun Pandan. Retrieved from http://e-journal.uajy.ac.id/id/ eprint $/ 4014$
Widiastuti, R. (2011). Kajian Stratejik Kelola Usaha Pada Industri Kecil Agel. Jurnal Riset Industri, $V$, 1-11. Retrieved from http://ejournal.kemenpe rin.go.id/jri/article/view/79

Yusuf, F. (2011). Perancangan Alat Pintal Tampar Pandan yang Ergonomis. Retrieved from http://ejournal.uajy.ac.id/id/eprint/ 1402 